\title{
RESPONS KULTURAL MASYARAKAT SASAK \\ TERHADAP ISLAM
}

\section{Asnawi}

\section{Abstract}

Islam reached Lombok island at sixteenth century, approximately at 1545. Its wellknown spreader was an expedition from Java led by Sunan Prapen son of Sunan Giri, one of the famous wali songo (nine religious leaders, the Islam spreader in Java). Before Islam reached this island, according to some historian, the indigenous Sasak-appellation to indigenous of Lombok people - had had their own traditional religion, Boda. Sometimes Boda was also called Majapabit Religion.

Method of spreading Islam at early time of Islam in this island was called threelinked system. A religious leader coming from Java had to teach three indigenous people and then made them be religious leaders. After mastering what was tanght they were considered religious leaders and, in turn, respectively have to teach another three candidates. This method of spreading gained effective outputs on one hand, but on other hand it also shaped a kind of viewpoint among indigenous people that the religious obligatories such as daily praying and fasting are only the duty of religious leaders not of common people.

Such unexpected point of view in turn has polarized the people into two groups, religious leaders and their common disciples. The later have point of view that they only do what their religious leader and king ask them to do, and this was the embryo of a local Islamic syncretism known as Wetu Telu. After time of Sunan Prapen, the Tuan Guru-a special call to Lombokness religious leaders-take responsiblity on islamization in this island, especially to the Wetu Telu disciples.

Keywords: Islam, Pola Penyebaran, Tuan Guru, Masyarakat Sasak, Respons Kultural, Wetu Telu, Waktu Lima.

DISKURSUS tentang sejarah masuknya Islam di Lombok, sampai saat ini masih diliputi oleh kekaburan sejarah. Penjelasan sejarah yang ada dalam berbagai literatur, masih bersifat spekulatif. Di samping itu, penjelasan tersebut didominasi berbagai pemahaman sejarah dengan dukungan fakta yang masih parsial. Sesungguhnya bila dilihat dari peta persoalan, maka hal terpenting yang masih menjadi wacana sentral adalah berbagai aspek utama 
berkaitan dengan periode kedatangannya, siapa pembawanya dan dari mana asal mulanya.

Kedatangan Islam di Lombok masih menjadi diskursus di kalangan para ahli sejarah dan akademisi. Sekali lagi, permasalahan ini merupakan kajian yang belum final bagi mereka yang peduli pada sejarah islamisasi Nusantara, khususnya masuknya Islam di Lombok. Di samping itu, karena sifat formulasi sejarah yang tidak pernah final dalam interaksinya, maka fakta dan data baru akan membawa perspektif yang baru pula.

Berbagai teori baru muncul dan berkembang disebabkan adanya beberapa penemuan arkeologis yang lebih baru dalam membuat kesimpulan di kalangan pengkaji sejarah. Penemuan baru ini menggunakan berbagai pendekatan keilmuan, sehingga bisa digunakan untuk menganalisis sejarah yang berkaitan dengan asal mula Islam dan siapa pembawa yang pertama ke Lombok. Dalam konteks ini, penulis berpegang pada arus utama (mainstream) melalui pengkajian terhadap literatur yang ada dengan menganalisis argumen-argumen yang mendukung pernyataannya.

\section{Akar Genealogis Islam Lombok}

Awal perkembangan Islam di Pulau Lombok diliputi ketidakjelasan, sekabur perkembangan Islam di Nusantara. Dalam hal ini, John Ryan Bartholomew melihat ada dua tema penting yang melembari sejarah masuknya Islam ke Lombok. Pertama, pulau yang seolah-olah tidur dan terbelakang ini merupakan situs dari bermacam-macam inkursi (baca: serbuan/penyerangan) yang mempengaruhi praktik-praktik dan kepercayaan Sasak (etnis asli Lombok). Kedua, ada seruan periodik namun konsisten terhadap purifikasi agama. Perubahan-perubahan sosial akibat dari inkursiinkursi ini memberikan stimulus perasaan akan kebutuhan untuk memperbarui agama. ${ }^{1}$

Tidak banyak tulisan mengenai kapan dan siapa yang membawa Islam masuk ke Lombok. Yang patut dicatat bahwa para ahli sejarah berpendapat bahwa sebelum Islam datang, Boda adalah agama asli etnis Sasak. Sebagian besar orang Sasak Boda ini secara resmi dicatat pemerintah sebagai pemeluk Budha, salah satu dari lima agama yang diakui pemerintah. Penganut agama ini menegaskan sebagai keturunan kerajaan Majapahit yang melarikan diri

1John Ryan Bartholomew, Alif Lam Mim: Kearifan Masyarakat Sasak, ter. Imron Rosyidi (Yogyakarta: Tiara Wacana, 2001), 93. 
ketika terjadi penyerangan Muslim. Terkadang orang Sasak Boda ini menyebut agama mereka dengan nama "Agama Majapahit". ${ }^{2}$

Tampaknya orang Sasak Boda ini tidak berlebihan mengklaim diri mereka sebagai penganut "Agama Majapahit" tersebut. Dalam kitab hukum Majapahit yang terkenal "Lontar Negara Kertahagama" karya Empu Prapanca secara eksplisit menyebut penaklukan Lombok oleh tentara Majapahit. Pada tahun 1334 M, kerajaan-kerajaan yang ada di pulau Lombok semisal Kerajaan Pematan, Kerajaan Lombok, Kerajaan Perigi, kerajaan Selampang, dan kerajaan Pejanggik, berhasil ditaklukkan oleh kerajaan Majapahit Jawa Timur yang dipimpin langsung Patih Gajah Mada. Menurut peninggalan sejarah yang dijumpai pada lempengan tembaga, disebutkan bahwa kedatangan Patih Gajah Mada didampingi oleh Datu Lumendung Sari. Pasukan Gajah Mada ini diberitakan mendarat pertama kali di desa Akar-Akar, wilayah Lombok Barat bagian utara. ${ }^{3}$ Tambahan lagi, keningratan Sasak hingga saat ini biasanya merujuk leluhur mereka pada Majapahit. Begitu juga, berbagai gelar dan dewa-dewa Boda, dengan jelas merupakan warisan Hindu-Jawa. ${ }^{4}$

Peninggalan pengaruh Hindu-Jawa masih dapat dibuktikan secara monumental di Sembalun, Sebuah Desa yang terletak di sebelah utara pulau Lombok. Goris dalam Aantekeningen Over Cost Lombok mengindikasikan, bahwa di Bayan dan Sembalun terdapat dua kampung tua yang diyakini sebagai tempat peristirahatan dan ditemukan keturunan Majapahit. Lebih jauh Goris menyatakan:

"Before the arrival of Islam, Lombok had experienced a long period of HinduBuddhist influence that reached the island through Java. The Negarakertagama, the 14th century palm leaf poem that was found on Lombok, places the island as one of the vassals of the Majapahit empire. According to the legends, two of the oldest villages on the island, Bayan and Sembalun, were founded by a prince of Majapahit". ${ }^{5}$

(Sebelum agama Islam datang, Lombok dalam waktu yang cukup lama pernah mengalami pengaruh agama Hindu Budha yang datang dari Jawa. Dalam Kitab Negarakertagama dijelaskan bahwa Lombok sudah ditemukan pada abad ke $14 \mathrm{M}$ dan takluk di bawah kerajaan Majapahit. Menurut legenda, ada dua kampung tua yaitu

2Ibid., 93-4.

${ }^{3}$ Muhammad Syamsu AS., Ulama Pembawa Islam di Indonesia dan Sekitarnya (Jakarta: Lentera Basritama, 1999), 114.

${ }^{4}$ Bartholomew, Alif..., 94.

${ }^{5}$ Goris R., Aantekeningen Over Cost Lombok (t.t.p.: t.p., 1963), 245. 
Bayan dan Sembalun sebagai bukti sejarah yang terdapat di pulau ini dan ditemukan oleh seorang pangeran Majapahit).

Sementara itu, agama Islam masuk di pulau Lombok kira-kira abad ke-16 M, dan penyebarnya yang terkenal adalah satu ekspedisi dari Jawa di bawah pimpinan Sunan Prapen, salah seorang putra Sunan Giri, salah satu dari sembilan wali (Wali Songo). Berdasarkan mitologi lokal yang dicatat dalam berbagai babad atau sejarah-sejarah yang ditulis di pohon palma, disebutkan bahwa Sunan Giri bertanggung jawab atas diperkenalkannya Islam ke Lombok pada tahun 1545 M.6 Berkembangnya Islam di pulau Lombok merupakan babakan sejarah baru dalam merubah keyakinan keagamaan etnis Sasak menjadi pemeluk agama Islam.

Selain itu, sumber lain menyebutkan:

"Islam came to Lombok until around the first half of the $16^{\text {th }}$ century. According to the legends, the first to propagate the new religion was a certain Sunan Prapen, son of the Sunan ratu of Giri. The palm leaf manuscript Babad Lombok which contains the history of Lombok describes how Sunan Prapen was sent by his Father on a military expedition to Lombok and Sumbawa Indonesia order to convert the population". ${ }^{7}$

(Agama Islam datang ke Lombok sekitar pertengahan abad ke-16. Menurut legenda, yang pertama kali mendakwahkan agama baru ini adalah Sunan Prapen putera Sunan Giri. Babad Lombok yang terdiri atas sejarah Lombok menggambarkan bahwa Sunan Prapen dikirim oleh orang tuanya memimpin sebuah ekspedisi militer ke Lombok dan Sumbawa untuk mengajak masyarakat (memeluk agama Islam).

Versi lain yang mendukung pernyataan di atas seperti yang dikatakan oleh Geoffrey, bahwa Islam diperkenalkan di pulau Lombok awal abad ke16 M. ${ }^{8}$ Setelah menaklukkan kerajaan Hindu Majapahit, penguasa Islam Jawa, Susuhunan Ratu Giri mengirimkan utusan-utusannya ke berbagai daerah di wilayah Nusantara. Utusan yang dikirim ke Lombok dan Sumbawa adalah Pangeran Prapen dan sering disebut sunan Prapen. ${ }^{9}$ Sunan Prapen tiba di Labuan Carik (pantai Anyar) dan sekarang menjadi kota Kecamatan Bayan. ${ }^{10}$ Menurut Sumber lain, Islam masuk ke Lombok melalui sebelah utara (Bayan) atas instruksi Sunan Pengging dari Jawa Tengah kira-kira

${ }^{6}$ Bartholomew, Alif...,94.

7http://www.abo.fi./comprel/temenos/temeno 32/ceder. Htm.

${ }^{8}$ Geoffrey E. Marrison, Sasak and Javanese (Leiden: KITLV Press, 1999$), 4$.

${ }^{9}$ Ibid., 4.

${ }^{10}$ Erni Budiwanti, Islam Sasak Wetu Telu versus Waktu Lima (Yogyakarta: LKIS, 2000), 287. 
permulaan abad ke-16 M.11 Setelah Lombok diislamkan, desa-desa lain menyusul satu demi satu diislamkan.

Terlepas dari berbagai versi tentang masuknya Islam ke Lombok, yang jelas bahwa Islam datang melalui Jawa dan tiba pertama kali di Lombok bagian utara pada abad ke-16 M, diperkenalkan pertama kali oleh misi yang dipimpin oleh Sunan Prapen, putera sunan Giri (salah satu dari Wali Songo). Pernyataan ini cenderung menjadi kesepakatan para ahli sejarah.

\section{Strategi Penyiaran Islam dan Respons Masyarakat Lombok}

Menurut babad Lombok, Sunan Giri memerintahkan tiga orang dari muridnya yaitu: Lembu Mangkurat untuk mengislamkan Banjarmasin, Dato' Banda mengislamkan Makasar, dan Sunan Prapen putera Sunan Giri ditugaskan untuk mengislamkan Pulau Lombok, Sumbawa dan Bali. ${ }^{12}$

Sunan Prapen datang ke Pulau Lombok dengan membawa sejumlah pengiring dan ulama-ulama dari Jawa. Di antaranya ada yang pandai memainkan "wayang". Agama Islam menyebar di Lombok melalui komunikasi pewayangan. Wayang Lombok menceritakan tentang pahlawan Islam seperti Amir Hamzah, Sayyidina 'Umar bin Khattâb, Lakon Perang Badar yang terkenal dengan sebutan "Awang Media", Sayyidinâ Alî bin Abî Thâlib yang dilukiskan sebagai "Selander Alam Dahur", dan Abû Lahab (si tukang fitnah) dinamai "Baktak". Sedang bahasa yang dipakai dalam pewayangan adalah bahasa Kawi/Jawa kuno. ${ }^{13}$

Pada umumnya, kiai yang datang bersama Sunan Prapen dari Jawa memiliki strategi dakwah dengan mengislamkan pertama kali raja-raja yang berkuasa. Pada mulanya mereka menggunakan metode dakwah non-formal, sesuai dengan kondisi saat itu. Selanjutnya, mereka melakukan pendekatan intensif terhadap elite kekuasaan, seperti pendekatan terhadap raja kerajaan Lombok di wilayah Lombok Timur beserta keluarganya. Orang pertama yang bersedia menerima ajaran Islam saat itu adalah Raden Mas Pahit, yang selanjutnya diikuti oleh sebagian besar rakyatnya. ${ }^{14}$

${ }^{11}$ Tim Penyusun Monografi, Monografi Daerah Nusa Tenggara Barat Jilid I (Jakarta: Departemen Pendidikan dan Kebudayaan, 1977), 15.

${ }^{12}$ Lalu Gde Suparman, Babad Lombok (Jakarta: Pusat Pembinaan dan Pengembangan Bahasa Departemen Pendidikan dan Kebudayaan, 1934 ), 195-6.

${ }^{13}$ Syamsu AS, Ulama..., 114-5.

${ }^{14}$ Harapandi Dahri, Wali dan Keramat dalam Persepsi Tradisional dan Modern (Mataram: IAIN Mataram Press, 2004), 135. 
Di Lombok saat itu tengah berkuasa raja-raja kecil yang merdeka dan berdiri sendiri. Meskipun secara formal raja-raja kecil itu tergabung dalam dua buah hegemoni yakni Kerajaan Bayan dan Kerajaan Selaparang. Tercatat dalam sejarah bahwa Dinasti Selaparang yang pertama kali menerima Islam. ${ }^{15}$ Upaya mengislamkan raja-raja di Lombok tidak mengalami kesulitan, karena dengan menceritakan bahwa raja-raja di Jawa sudah memeluk Islam, maka mereka dengan senang hati juga memeluk agama Islam. Hal ini disebabkan raja-raja di Lombok mempunyai hubungan pertalian darah dengan raja-raja di Jawa terutama kerajaan Majapahit. Hal ini dapat dibuktikan dengan silsilah yang ada. ${ }^{16}$ Fakta lain yang dapat disaksikan sampai sekarang adalah nama beberapa desa dan kota di Lombok banyak yang mempunyai nama yang sama dengan desa dan kota di bekas wilayah kerajaan Majapahit di Jawa, seperti Surabaya, Kediri, Kuripan, Gresik, Wanasaba (Wonosobo), Mataram dan lain-lain.

Setelah raja Selaparang memeluk agama Islam, kerajaan Selaparang Hindu kemudian berubah menjadi kerajaan Selaparang Islam dan membawa spirit Islam masuk ke dalam kebudayaan Sasak. Ini berarti bahwa sejarah dan kebudayaan Sasak mengalami proses transformasi berdasarkan kehidupan keagamaan yang dianutnya.

Dengan masuk Islam rajanya, maka seluruh rakyatnya dinyatakan masuk Islam atau harus mengakui Islam sebagai agamanya. ${ }^{17}$ Akibatnya, seluruh wilayah kerajaannya diklaim memeluk agama Islam. Sementara di tempat yang jauh dari pusat kerajaan masih terdapat penganut yang masih sangat awam. Hanya pengakuannya saja yang Islam, tetapi keyakinan (aqidah) dan praktik keagamaannya masih bercampur dengan kepercayaan dan adatistiadat lama serta agama nenek moyangnya. Seperti yang telah disebutkan bahwa sebelum agama Islam datang agama yang dianut masyarakat Lombok menganut agama Siwa-Budha atau yang dikenal dengan Boda. ${ }^{18}$

Jika digambarkan lebih terinci, pada sikuens pertama, Islam tidak langsung secara merata diterima oleh lapisan masyarakat bawah (grass root). Sebagai

${ }^{15}$ Lihat kembali Syamsu AS, Ulama..., 114.

${ }^{16}$ Tim Penyusun Monografi, Monografi..., 80.

${ }^{17} \mathrm{Hal}$ ini juga bisa dilihat pada pekembangan partai politik, ketika tokohnya masuk partai A, maka otomatis jamaahnya masuk pada partai A tersebut, atau dinyatakan masuk pada partai tokohnya. Ini merupakan warisan budaya sejak dahulu dan mungkin akan berlanjut pada hal-hal tertentu yang berkaitan dengan sikap sosial.

${ }^{18}$ Fathurrahman Zakaria, Mozaik Budaya Orang Mataram (Mataram: Yayasan Sumurmas Al-Hamidi, 1998), 17. 
perbandingan, di Jawa misalnya, Islam semula hanya dipraktikkan oleh sekelompok kecil penganut Islam yang aktif dan bertugas membawa pesanpesan Islam. Dengan demikian, sebagian besar penduduk tetap menganut kepercayaan nenek moyang mereka. Keadaan yang sama dijumpai juga di daerah lain di Indonesia seperti di Minangkabau. ${ }^{19}$ Hal yang sama terjadi juga di masyarakat etnis Sasak. Orang sasak Boda, khususnya yang masih tinggal di pegunungan dan tempat-tempat yang terasing, pada tingkat tertentu masih melanjutkan sistem keyakinan nenek moyangnya. Kelompok masyarakat inilah barangkali yang menjadi penganut Wetu Telu. ${ }^{20}$

Nampaknya para penyebar agama Islam bertindak sangat hati-hati serta lemah lembut dan tidak dengan pendekatan revolusioner. Artinya ajaran agama diajarkan secara bertahap sesuai dengan kemampuan mereka yang menerimanya. Selanjutnya, apabila telah berhasil mengislamkan satu desa, kemudian berpindah ke desa lain dengan meninggalkan seorang kiai untuk menyempurnakannya dan mendampingi raja. Kiai yang ditugaskan itu juga menyempurnakan ajaran agama Islam dengan cara bertahap dan demikian seterusnya.

Tahap pertama penyebaran Islam melalui raja yang mengeluarkan titah (baca: komando) kepada rakyatnya. Hal ini dapat dilihat misalnya setiap anak laki-laki yang sudah berumur tujuh tahun atau sebelum baligh, diwajibkan khitan. Begitu juga semua rakyat diperintahkan merayakan hari-hari besar agama Islam, seperti peringatan Maulid Nabi Muhammad SAW., perayaan bulan Muharram, bulan Shafar, bulan Sya'ban, Idhul Fitri, Idhul Adha, dan

${ }^{19}$ Azyumardi Azra, Renaisans Islam Asia Tenggara: Sajarah Wacana dan Kekuasaan (Bandung: Remaja Rosdakarya, 1999), 35.

${ }^{20}$ Wetu Telu inilah yang masih berkembang di Bayan dan pernah diteliti oleh Erni Budiwanti dalam bukunya Islam Sasak. Wetu Telu versus Waktu Lima. Lebih jauh Erni menyatakan bahwa kalau orang-orang Waktu Lima menafsirkan Wetu Telu sebagai waktu tiga (waktu telu) dan mengaitkan makna ini dengan reduksi seluruh ibadah Islam menjadi tiga (baca: telu). Orang Bayan penganut Wetu Telu, menolak penafsiran semacam itu. Pemangku adatnya mengatakan, term wetu sering dikacaukan dengan waktu. Wetu berasal dari kata "metu" yang berarti "muncul" atau "datang dari". Sedangkan "telu" artinya "tiga". Secara simbolis makna ini mengungkapkan bahwa semua makhluk hidup muncul (baca: metu) melalui tiga macam sistem reproduksi, yaitu: melahirkan (disebut menganak), bertelur (disebut menteluk) dan berkembang biak dari benih (disebut juga mentink). Term Wetu Telu juga tidak hanya menunjuk kepada tiga macam sistem reproduksi, tetapi juga menunjuk pada kemahakuasaan Tuhan yang memungkinkan makhluk hidup untuk hidup dan mengembangkan diri melalui mekanisme reproduksi tersebut. Lihat Erni Budiwanti, Islam Sasak Wetu Telu versus Waktu Lima (Yogyakarta: LKIS, 2000), 136. 
hari besar lainnya. Demikian juga peraturan yang berdasarkan Islam dititahkan oleh raja menjadi undang-undang dan peraturan yang harus dipatuhi oleh semua rakyat. ${ }^{21}$

Metode yang dikembangkan supaya agama Islam berkembang dengan cepat, dijalankan sistem berantai tiga. Kiai yang datang dari Jawa, diharuskan mendidik tiga orang kiai. Apabila tiga orang kiai itu sudah dianggap mampu (baca: memiliki otoritas keagamaan), diharuskan mendidik tiga orang murid. Selanjutnya, apabila tiga orang murid itu sudah dianggap mampu, maka dilantik menjadi kiai. Cara ini menimbulkan kesan seolah-olah hanya kiai penghulu saja yang berkewajiban melaksanakan kewajiban-kewajiban agama seperti shalat dan puasa. Kenyataan ini melahirkan dua kelompok sosial yaitu kelompok kiai dan pengikut kiai yang masih awam.

Golongan yang masih awam ini mempunyai paham hanya melaksanakan kewajiban-kewajiban yang diperintahkan oleh kiai dan rajanya saja. Seperti merayakan hari-hari tertentu dan kewajiban membaca syahadatayn (dua kalimah syahadah) ketika menikah. Hal ini berlangsung bertahun-tahun dari satu generasi ke generasi berikutnya. Sehingga timbul dalam pemahaman mereka bahwa memang keadaan yang demikian itulah ajaran agama yang dikehendaki dan yang mesti dilakukan. Tidak mengherankan jika kemudian penyebar agama Islam yang datang berikutnya yang akan mengajarkan ajaran Islam untuk menyempurnakan ajaran yang sudah mereka pahami, selalu mendapatkan tantangan dari para kiai penghulunya dan tokoh masyarakat yang sudah puas dengan keadaan itu. ${ }^{22}$

Akibatnya, maka yang berkewajiban melaksanakan ibadah seperti shalat dan puasa hanya kiai saja, sedangkan rakyat menyerahkan kewajibannya kepada kiai penghulu mereka. Sebagai perimbangannya, mereka menyerahkan semua zakat fitrah ${ }^{23}$ dan sedekah lainnya pada hari-hari tertentu kepada kiai mereka masing-masing, karena merasa berutang budi

${ }^{21}$ Tim Penyusun Monografi, Monografi..., 81.

${ }^{22}$ Keadaan ini pernah penulis alami ketika mahasiswa STAIN Mataram melaksanakan Kuliah Kerja Nyata pada tahun 1997 dan 1998 di Desa Bayan terutama Bayan Belek (Bayan besar). Sewaktu melaksanakan program pembinaan keagamaan di masyarakat Bayan tersebut, mendapat tantangan dari beberapa tokoh atau kiainya.

${ }^{23}$ Ada dua macam zakat fitrah yang ditunaikan yaitu "zakat fitrah urip" dan "zakat fitrah pati”. Zakat fitrah urip adalah zakat fitrah orang yang masih hidup. Sedang zakat fitrah pati adalah zakat fitrah dari orang yang sudah meninggal dunia, yang dikeluarkan oleh keluarganya yang masih hidup. Kedua macam zakat fitrah itu diserahkan kepada kiai mereka dengan niat mencari kesejahteraan dan perbaikan kehidupan di dunia dan akhirat. 
pada kiainya. Praktik keagamaan seperti ini masih terjadi di kalangan penganut Wetu Telu.

Islam yang diperkenalkan oleh Sunan Prapen dan para penerusnya nampaknya hanya menekankan konsep keimanan dan ketauhidan dengan pendekatan budaya. Pembinaan Islam yang diutamakan adalah kesadaran ketuhanan dan ibadah dengan pendekatan yang bersifat sufistik. Pola sufisme sinkretik dipandang efektif untuk syiar Islam saat itu dan lebih mudah diterima. Sampai dengan penghujung abad ke-17 M, Islam sudah tersebar di seluruh pulau Lombok. ${ }^{24}$

Penyebaran agama Islam di Lombok disesuaikan dengan kondisi dan situasi saat itu. Adat-istiadat dan kesenian disesuaikan dengan ketauhidan, artinya selama hal tersebut tidak merusak ketauhidan, dibiarkan berkembang. Mereka diajarkan mengucap dua kalimah syahadat (syahadatayn) dan ikrar tawbat. Ajaran fiqh banyak ditulis dalam bahasa daerah yang bercampur dengan bahasa Kawi, digubah dalam bentuk sya'ir, selanjutnya ditembangkan dan ditulis dalam huruf Jejawen (huruf sasak). Di setiap awal tulisan atau uraian selalu diawali dengan pujian kepada Tuhan Yang Maha Esa seperti:

"Bismillah hamba miwiti, banibut mawaning Allah kang murab bing dunie riko, bing kang asih bing akbirat. Kang pinuji tan pegat, tan ana ratu lian agung, setubune amung Allah".

(Bismillah hamba mulai dengan menyebut nama Allah yang Maha Pemurah dan Pengasih di dunia dan akhirat)

Sedang dua kalimah syahadahnya berbunyi:

"Werub ingsun norana pangeran iyaning Allah, lan werub ingsun Nabi Muhammad utusan Allah atau Asybadu ingsun sining werub ansyaksini angestoken norana Pangeran sebenere bangging Allah Pangeran kan sebenere setubune Nabi Mubammad utusan Allab". ${ }^{25}$

(Hamba bersaksi tiada Tuhan selain Allah dan Nabi Muhammad adalah utusan Allah).

Kalimat tobatnya sendiri berbunyi: "Ingsun anede pengampuranung Allah, hing dosa hamba ingkang agung alit, ingkang nyata ingkang samar" (Hamba mohon ampun kepada Allah atas dosa yang sudah lalu yang nyata dan yang tersembunyi). Kemudian dilanjutkan dengan ber-istighfar tiga kali. ${ }^{26}$

${ }^{24}$ Marrison, Sasak..., 5.

${ }^{25}$ Tim Penyusun Monografi, Monografi...,14.

${ }^{26}$ Ibid. 


\section{Wajah Islam Lombok: "Waktu Lima" versus "Wetu Telu"}

Agama Islam di Lombok dalam praktiknya ada dua tipe, yaitu praktik Islam Waktu Lima (W5) dan Islam Wetu Telu (W3). Islam Waktu Lima dalam praktik keagamaan sesuai dengan ajaran Islam puritan. Kelompok ini disebut juga "Muslim ortodoks". Menggambarkan Muslim ortodoks sebagai "Waktu Lima" (biasanya dihaluskan sebagai "Lima Jalan"), merupakan indikasi eksplisit bahwa kelompok Muslim ini, mengakui kewajiban untuk memenuhi lima rukun Islam yang diawali dengan syahadat, shalat, puasa, zakat, dan menunaikan ibadah haji ke Makkah. ${ }^{27}$ Sedang kelompok Muslim Wetu Telu dalam praktik kehidupan sehari-hari, masih sangat kuat berpegang teguh pada adat-istiadat nenek moyang. Pelaksanaan keagamaan hanyalah dikerjakan oleh kiai dan penghulu mereka. Dalam masyarakat Wetu Telu, masih tersisa pengaruh ajaran pribumi dan agama Hindu. Hal ini dapat dibuktikan dengan dipeliharanya sarana peribadatan yang disebut Pedewaq sebagai tempat pemujaan, meskipun mereka mengucapkan dua kalimah syahadat menurut ketentuan Islam. ${ }^{28}$

Pelaksanaan ritual kelompok Wetu Telu ini bervariasi, misalnya shalat zuhur hanya sekali pada hari Jum'at, atau sembahyang pada hari Kamis sore, atau sembahyang subuh pada dua hari raya. Shalat yang diikuti oleh jama'ah di masjid hanya shalat dua hari raya yaitu Idul Fitri dan Idul Adha. Puasa Ramadhan dilakukan hanya tiga hari yaitu awal, tengah, dan akhir bulan. ${ }^{29}$

Secara umum, ritual-ritual yang diselenggarakan Islam Wetu Telu terbagi menjadi dua kelompok. Pertama, kelompok ritual yang berkaitan dengan harihari besar Islam. Dan kedua, ritual-ritual yang berbentuk upacara-upacara adat yang telah ditentukan oleh adat di mana mereka berada. Ritual-ritual yang berkaitan dengan hari-hari besar Islam pada prinsipnya tidak berbeda dengan yang diselenggarakan oleh Islam Waktu Lima, namun penetapan waktu dan sistem perayaannya terdapat perbedaan. Perayaan Islam Waktu Lima, mengikuti kalender yang ditentukan oleh Departemen Agama RI dan biasanya mengundang para tokoh-tokoh agama (Tuan Guru/kiai) ataupun ulama. Sedangkan Islam Wetu Telu, perayaan hari-hari besar keagamaan berpedoman pada naptu (perhitungan kalender tradisional). ${ }^{30}$

\footnotetext{
${ }^{27}$ Lihat Bartholomew, Alif..., 100.

28Zakaria, Mozaik..., 138.

${ }^{29}$ Ibid.,139.

30Dahri, Wali..., 154.
} 
Terdapat sumber lain yang mengatakan mereka hanya baru mengenal tiga rukun dari lima rukun Islam. ${ }^{31}$ Selain itu ada yang mengatakan mereka hanya mengerjakan tiga shalat yaitu, shalat Jum'at, shalat 'Idhul Fitri, dan shalat 'Idhul Adha. Meskipun demikian, yang pasti, Wetu Telu adalah paham keagamaan dalam masyarakat Lombok yang belum sesuai tata cara ritual keagamaannya dengan syari'at Islam. Atas dasar itu, kelompok ini disebut sebagai "Muslim sinkretis". 32

Mengapa terjadi hal semacam itu? Ini setidaknya disebabkan karena dalam mendakwahkan Islam di awal-awal perkembangannya belum tuntas, sebagai konsekwensi para pendakwah yang berpindah-pindah dari satu desa ke desa lain. Di samping itu, materi ajaran agama disampaikannya secara bertahap. Karena daya lentur ajaran Islam, tata nilai yang telah berkembang dalam kehidupan masyarakat sebelum datangnya Islam, tidak serta merta diganti. Akibatnya, masih ada budaya lama yang masih diterapkan bersamaan dengan ajaran Islam yang baru diterima masyarakat Lombok. Oleh karena masih baru dalam proses memeluk Islam melalui tahap permulaan, yaitu mengucap dua kalimah syahadat, sehingga pengetahuan tentang shalat dan tata cara shalat umpamanya, belum sempurna. Mereka itulah kemudian yang menjadi penganut Wetu Telu.

\section{Upaya Islamisasi dan Peran Tuan Guru}

Paham Wetu Telu di atas pada mulanya berkembang di wilayah Lombok Tengah bagian selatan. Namun pada perkembangan selanjutnya, sebagian besar dari mereka telah banyak yang melaksanakan ajaran Islam dengan sempurna berkat kegigihan para kiai (baca: Tuan Guru) yang telah menimba ilmu pengetahuan di Makkah sejak abad ke-19 M. Para Tuan Guru yang kembali ke pulau Lombok dan berdakwah serta membimbing masyarakat penganut $W$ etu Telu dengan cara-cara ritual Islam Waktu Lima seperti, TGH. Ali Batu, Guru Bangkol, TGH. Muhammad Sidik, dan di Praya dilanjutkan oleh TGH. Makmun. ${ }^{33}$

Deretan Tuan Guru tersebut merupakan penyiar Islam generasi awal yang menekankan aspek fiqh berupa kewajiban pokok seperti shalat, puasa,

${ }^{31}$ Tim Penyusun Monografi, Monografi..., 80.

32 Bartholomew, Alif..., 98.

33Wawancara dengan H. Fathurrahman Zakaria tanggal 23 Maret 2004. la adalah penulis buku Mozaik Budaya Orang Mataram yang dalam buku tersebut terdapat ulasan tentang beberapa tokoh tarekat di Lombok. TGH adalah singkatan dari Tuan Guru Haji. 
zakat, dan haji dan ditambah dengan wirid tarekat Naqsyabandiyah bagi kalangan masyarakat yang dianggap sudah layak. Jasa para Tuan Guru tersebut masih dapat disaksikan dengan banyaknya para peziarah ke kubur mereka sampai sekarang. Hasil dari dakwah mereka belum dikatakan dapat mengeliminir sepenuhnya paham Wetu Telu yang masih terdapat di pelosokpelosok desa karena berbagai faktor, semisal jarak yang berjauhan dan pengaruh tokoh setempat yang masih enggan menerima kedatangan para Tuan Guru tersebut, terlebih mengikuti ajarannya.

Di bawah kekuasaan Belanda, masyarakat Sasak mengalami kontrol dan penindasan yang lebih keji daripada penguasa-penguasa sebelumnya. Para pemimpin Islam, seperti Tuan Guru, yang telah melakukan dakwah untuk menyiarkan ajaran-ajaran Islam di kalangan Wetu Telu sebelum kedatangan Belanda, akhirnya menjadikan Islam sebagai dasar perjuangan ideologis untuk melawan penjajah Belanda yang dianggap kafir.

Belanda sendiri telah lama tertarik untuk menguasai Lombok. Pada tahun 1894, mereka telah mulai menjajah pulau Lombok dengan membantu beberapa tokoh Sasak atas nama membebaskan orang-orang Sasak dari maharaja Bali. Ekspedisi militer pertama mengalami kegagalan. Namun dengan penambahan kekuatan, mereka dengan cepat mampu menguasai pulau Lombok. Dalam hal ini, peran perdagangan Raja George dari Inggris yang tinggal di Ampenan, tidak dapat diabaikan dalam memainkan konflik yang ada. ${ }^{34}$

Sepanjang pemerintahan kolonial Belanda, Tuan Guru mengalihkan gerakan dakwah mereka menjadi pemberontakan-pemberontakan lokal yang bernuansa keagamaan untuk menghalau Belanda. Gerakan pemberontakan yang dipimpin oleh para Tuan Guru memperoleh pengikut yang banyak. Di antara Tuan Guru yang terlibat langsung dalam pemberontakan itu adalah TGH. Ali Batu dari Sakra Lombok Timur, TGH. Muhammad Sidik dari Karang Kelok Lombok Barat, dan Guru Bangkol dari Praya Lombok Tengah. Tokoh-tokoh tersebut merupakan mursyid Syaikh Ahmad Khatib Sambas di Makkah dan Syaikh Abdul Karim Banten ${ }^{35}$ yang mengembangkan

${ }^{34}$ Bartholomew, Alif..., 97.

35Syaikh Ahmad Khatib wafat sekitar tahun 1878 M, dan kedudukannya sebagai pimpinan tarekat kemudian digantikan khalifahnya, Syeikh Abdul Karim Banten yang bermukim di Makkah. Karisma Syaikh Abdul Karim menyebabkan tarekat Qadîriyah wa Naqsyabandiyah berkembang pesat di Banten dan daerah lainnya, dari Sumatera Selatan sampai Lombok. Lihat Martin Van Bruinessen, Kitab Kuning dan Tarekat (Bandung : Mizan, 1995), 217. 
tarekat Qâdiriyah dan Naqsyabandiyah. Mereka merupakan tokoh-tokoh kuat yang mengobarkan semangat anti penjajahan dan penindasan dari pihak manapun, ${ }^{36}$ sehingga gerakan anti kolonial dan anti penindasan menjadi suatu gerakan yang membangkitkan semangat berperang melawan penjajah dan penindasan. ${ }^{37}$

Mengenai perlawanan melawan penjajahan dan penindasan ini, Martin Van Bruinessen menjelaskan bahwa pada tahun 1891 terjadi pemberontakan dari kaum Muslimin suku Sasak melawan orang-orang Bali yang menguasai sebagian besar pulau itu. Berbeda dengan pemberontakan-pemberontakan sebelumnya, pemberontakan kali ini tidak mudah dipadamkan dan berlangsung terus sampai 1894. Pemberontakan itu berpusat di Praya (Lombok Tengah) dan pucuk pimpinannya adalah Guru Bangkol, seorang bangsawan setempat, yang sekaligus salah seorang guru tarekat Naqsyabandiyah. ${ }^{38}$

Gerakan yang dipimpin oleh pemimpin tarekat cukup mengkhawatirkan pihak penjajah Belanda, ketika terjadi pemberontakan di Banten tahun 1888 M. Pada waktu itu, Engelenberg seorang Kontrolir Belanda, sedang berada di Banten. Dari peristiwa itu tumbuh kecurigaan yang kuat dalam dirinya terhadap gerakan tarekat. Ia memperhatikan bahwa para pemimpin pemberontakan Sasak, ternyata ada kaitannya dengan tarekat. ${ }^{39}$ Pemerintah Belanda mempunyai kesimpulan bahwa tarekat mengancam kekuasaannya, akibatnya pihak Belanda berusaha secara aktif mencari informasi mengenai kegiatan-kegiatan tarekat. Di Praya umpamanya, TGH. Makmun --salah seorang pemimpin tarekat Qâdiriyah wa Naqsyabandiyab-- tidak luput dari incaran. Namun, tatkala penyelidik Belanda tiba di depan kampungnya yang bernama Karang Lebah, mereka hanya melewatinya saja dengan berkali-kali bolak-balik. Akhirnya, mereka menjadi bosan karena kelelahan dan tidak dapat menemui TGH. Makmun. ${ }^{40}$

36Zakaria, Mozaik..., 144.

${ }^{37}$ Inggela Gerdin, The Unknown Balinese: Land Labour and Inequality in Lombok (Sweden: Vasastadents Bokbinderi, 1982), 38.

${ }^{38}$ Martin van Bruinessen, Tarekat Naqsyabandiyah di Indonesia (Bandung: Mizan, 1992), 28.

${ }^{39}$ Ibid.

40 Penjelasan ini disampaikan oleh TGH. Muhammad Najamuddin Makmun salah seorang putera TGH. Makmun pada tanggal 15-1-2002. TGH Muhammad Najamuddin Makmun juga mengembangkan tarekat Qadîriyah dan Naqsyabandiyah di pulau Lombok. 
Selama masa penjajahan Belanda, gerakan dakwah yang dipimpin Tuan Guru makin meningkatkan polarisasi antara Wetu Telu dan Waktu Lima. Jika kelompok pertama, memberikan loyalitas mereka kepada para bangsawan Sasak sebagai pemimpin tradisional dan kuat mempertahankan adat lokal, maka kelompok kedua mengikuti para Tuan Guru sebagai pemimpin keagamaan kharismatik mereka.

Dalam babak sejarah berikutnya, Jepang menggantikan Belanda di Lombok untuk suatu periode yang singkat antara 1942 dan 1945. Sesudah itu, selama perang kemerdekaan Indonesia, Belanda berusaha untuk menguasai kembali Lombok dan pulau-pulau Indonesia lainnya, tetapi tidak berhasil. Lombok merdeka pada tahun 1946 sebagai bagian dari wilayah Indonesia.

TGH. Mutawalli seorang Tuan Guru yang dapat digolongkan generasi berikut dari tokoh-tokoh agama etnis Sasak, mendakwahkan ajaran Islam secara intensif kepada masyarakat penganut Wetu Telu, disamping juga menyebarkan dakwah Islam di pondok pesantrennya Dâr al-Yatâmâ wa alMasâkîn yang didirikan pada tahun I960.41 la sangat terkenal karena kepiawaiannya menembus desa-desa Wetu Telu dan menggunakan metode yang tidak lazim untuk mengislamkan kelompok Wetu Telu. la mengibaratkan dirinya sebagai seorang perambah hutan, yang pada giliran selanjutnya para Tuan Guru lain yang menyempurnakannya. Hal terpenting yang diharapkan adalah bahwa penganut Wetu Telu memeluk Islam versi Waktu Lima dan melaksanakan shalat lima waktu sehari semalam. Maksud penyataannya adalah ia sekedar mengislamkan penganut Wetu Telu tersebut menjadi Waktu Lima, selanjutnya tokoh-tokoh agama lainnya yang mengajarkan tata cara pelaksanaan kewajiban-kewajiban sebagai seorang Muslim secara lebih mendetail. 42

Untuk memperdalam pengetahuannya tentang agama Islam, penganut Wetu Telu diserahkan kepada Tuan Guru yang lain untuk menempanya. Sekalipun demikian antara dia, Tuan Guru, dan ustadz yang lain tidak mempunyai hubungan koordinatif, tetapi lebih merupakan ikatan hubungan moral kewajiban berdakwah. Masyarakat Jerowaru Lombok Timur tempat

${ }^{41}$ Wawancara dengan TGH. Sibawaih, salah seorang putera TGH. Mutawalli pada tanggal 28 Maret 2004.

${ }^{42}$ Wawancara dengan A. Muharis, salah seorang warga masyarakat di Kecamatan Praya (Lombok Tengah) pada tanggal 18 April 2004. 
Pondok Pesantrennya dibangun, meyakini bahwa TGH. Mutawalli menyerupai seorang Wali Jawa zaman dahulu yang memiliki kekuatan mistik.

Pendekatan yang digunakan sebelum melaksanakan dakwah adalah dengan mempelajari mitologi pada komunitas Wetu Telu tertentu. Mula-mula ia mengutus murid-murid kepercayaannya untuk menghimpun legenda dan mitos setempat dari para tetua desa. ${ }^{43}$ la memahami bahwa komunitas Wetu Telu sangat menggemari pemujaan terhadap masa lalu, dan karena itu ia menampilkan diri berminat mempelajari silsilah penduduk setempat untuk mengetahui apakah ada hubungan antara keturunannya sendiri dengan keturunan masyarakat setempat.

Pendekatan ini membuat para tokoh adat setempat tidak segan-segan membuka lontar yang memuat silsilah mereka. TGH. Mutawalli termasuk yang bisa membaca lontar yang ditulis dalam bahasa Sasak maupun bahasa Jawa. Setelah mempelajari dan memahami mitos setempat, ia merepresentasikan diri sebagai salah seorang figur yang dimaksud dalam legenda itu dan melakoni perannya.

Ada suatu penuturan yang disampaikan oleh salah seorang tokoh di kecamatan Pujut Kabupaten Lombok Tengah. Tokoh tersebut menyatakan bahwa warga $W$ etu Telu di desa Sengkol Kecamatan Pujut Lombok Tengah, mempunyai mitos bahwa suatu saat nanti akan datang seorang penguasa yang bijak dan adil tempat mereka menyandarkan diri dan sekaligus sebagai panutan. Akan ada tanda-tanda yang menyertai kedatangannya. Kedatangannya tidak bisa dipastikan dan mendadak, seperti burung nuri yang sedang terbang. Bumi akan goncang ketika ia mendarat. ${ }^{44}$

Setelah mempelajari kisah itu, TGH. Mutawalli mengenakan jubah hijau ketika ia mendatangi sebuah masjid tua ${ }^{45}$ yang terletak di puncak gunung Pujut di Sengkol. Dengan kekuatan mistiknya, terjadilah gempa kecil di sekeliling masjid tua itu dengan mempergunakan bantuan jin. Kedatangan TGH. Mutawalli secara mendadak dan diiringi gempa kecil itu, mengakibatkan komunitas masyarakat di tempat itu menjadikan TGH. Mutawalli sebagai figur yang mereka nantikan.

${ }^{43}$ Budiwanti, Islam..., 292.

${ }^{44}$ Mitos ini memang cukup berkembang di sebagian masyarakat Lombok Tengah. Penulis sering mendengarkan mitos ini dari para tetua di kampung tempat kelahiran penulis di Lombok Tengah.

${ }^{45}$ Masjid ini terletak di wilayah Sengkol Pujut (Lombok Tengah), dan di dalamnya masih tersimpan sampai sekarang al-Qur'an yang ditulis dengan tulisan tangan. 
Oleh karena itu, secara perlahan namun pasti, pengaruh TGH. Mutawalli semakin kuat di masyarakat Wetu Telu Sengkol Lombok Tengah dan sekitarnya dan kini menjadi Islam Waktu Lima. ${ }^{46}$ Ustadz Najam, seorang da'i di Bayan Belek (Kecamatan Bayan), meyakini kekuatan gaib yang dimiliki TGH. Mutawalli yang diperoleh karena kemampuannya menaklukkan jin. ${ }^{47}$

Dalam periode yang relatif bersamaan, upaya menyempurnakan pengetahuan keagamaan masyarakat Wetu Telu tidak hanya dilakukan oleh TGH. Mutawalli, akan tetapi upaya suci itu dilakukan oleh beberapa Tuan Guru dengan muridnya yang setia seperti di Lombok bagian utara melalui pengajian yang rutin dilaksanakan oleh TGH. Muhammad Zainuddin Abdul Majid dengan organisasi Nabdlatul Wathan $(\mathrm{NW})^{48}$ yang didirikannya dan tersebar ke seluruh Lombok melalui murid- muridnya.

Selain itu, dapat disebutkan TGH. Shafwan Hakim dengan Pondok Pesantrennya Nurul Hakim, mengembangkan sayap dakwah ke Lombok Utara dengan sasaran utama penganut Wetu Telu dan kaum Muslim sekitarnya. Demikian halnya TGH. Hazmi Hamzar dengan Pondok Pesantren Marâqi al- Ta'lîmât yang telah didirikan oleh orang tuanya, yaitu TGH. Zainuddin. la membina beberapa majelis taklim sebagai tempat pembinaan masyarakat Muslim di Lombok Utara dan penganut Wetu Telu sebagai sasaran utamanya. Pembinaan masyarakat Wetu Telu tampaknya dilaksanakan secara bersama dan koordinatif oleh para Tuan Guru yang ada di pulau Lombok.

Adapun pembinaan dan penyempurnaan paham keagamaan masyarakat Wetu Telu yang terdapat di Kecamatan Pujut Lombok Tengah bagian Selatan, dilaksanakan Tuan Guru atau tokoh agama yang berasal dari Lombok Tengah. Ini dapat dicontohkan semisal TGH. Muhammad Faishal dengan pengajian-pengajian dan pondok-pondok pesantren yang bernaung di bawah organisasi Nahdlatul Ulama. Bagitu juga TGH. Muhammad Najamuddin Makmun dengan majelis-majelis taklim pada pondok pesantren Darul

46-Wawancara dengan H.L. Marzuki pada tanggal 16 Maret 2001.

${ }^{47}$ Budiwanti, Islam..., 293.

${ }^{48}$ Organisasi Nahdlatul Wathan (NW) tersebut merupakan organisasi sosial, pendidikan, dan dakwah yang berazaskan Islam Abl al-Sunnah wa al-Jamâ'ah yang bermadzhab hukum Syafi'i. Organisasi ini berdiri pada tanggal 17 Agustus 1936 berdasarkan akte notaris pemerintah Hindia Belanda dengan nama Nahdlatul Wathan Diniyyah Islamiyyah (NWDI). Lihat Fathurrahman Muhtar, "Gerakan dan Pemikiran Dakwah Kiai Hamzanwadi dalam Bidang Pendidikan (1934-1997)” dalam Tasamuh Volume II Nomor 1 Jnauari-Juni 2004, 85. 
Muhajirin dan beberapa pondok pesantren yang berada di bawah pembinaan Pondok Pesantren Darul Mubajirin yang berlokasi di daerah Praya Lombok Tengah.

Jika melihat perkembangan Islam setelah era wali-wali dari Jawa, tampaknya revitalisasi Islam di Lombok lebih banyak diprakarsai oleh Tuan Guru dengan dukungan para pengikut setianya, ketimbang pemerintah. Komitmen para Tuan Guru untuk meneruskan ajaran Islam melalui dakwah, merupakan implementasi dari ketaatannya kepada Rasulullah SAW. Kesetiaan para pengikut Tuan Guru kepada tokoh panutannya sampai pada tingkat tertentu, didasari oleh prinsip "sami'nâ wa 'atha'nâ" (kami dengar dan kami ta'ati). Prinsip ini, mendorong mereka untuk mengikuti para tokohnya (baca: Tuan Guru tersebut) yang sangat mereka percayai dan telah berjasa membimbing mereka ke jalan yang benar.

Sebagaimana diketahui bahwa dakwah adalah upaya penyebaran dan penerangan Islam yang tiada akhir dalam kehidupan. Doktrin inilah yang mendorong para tokoh agama untuk menyebarkan ajaran Islam dalam segala situasi dan kondisi politik. Meskipun terdapat pendukung tertentu dari kelompok organisasi keagamaan yang sekali waktu mengubah afiliasi politik dengan tujuan untuk kemajuan organisasi dan lembaga-lembaga pendidikan yang mereka bangun, tetapi tidak mengurangi kegigihan mereka dalam mendakwahkan ajaran Islam. Dengan ungkapan lain, berdakwah adalah aktifitas otonom para Tuan Guru yang sama sekali kebal dari pengaruh rezim politik yang berkuasa.

Para Tuan Guru yang menyebarkan Islam di pulau Lombok, umumnya pernah menuntut ilmu di Timur Tengah, baik secara formal maupun informal melalui halaqah-balaqah pengajian. Sumber dinamika Islam abad ke17 dan ke-18 M adalah melalui jaringan ulama yang berpusat di Makkah dan Madinah. Posisi penting kedua kota suci ini terutama dalam kaitan dengan ibadah haji, mendorong sejumlah guru (ulama) dan pencari ilmu dari berbagai wilayah dunia Muslim-termasuk dari pulau Lombok-untuk bermukim dan menuntut ilmu. Mereka bermukim di sana, yang pada gilirannya menciptakan semacam jaringan keilmuan yang menghasilkan wacana ilmiah yang unik. Sebagian besar mereka yang terlibat dalam jaringan keilmuan ini mengadakan upaya-upaya sadar untuk memperbarui dan merevitalisasi ajaran-ajaran Islam, terutama yang berkaitan dengan akidah, ibadah, dan peningkatan sosio-moral masyarakatnya. ${ }^{49}$

${ }^{49}$ Lihat Azra, Renaisans..., 16. 
Memahami proses-proses transmisi gagasan pembaruan menjadi semakin penting dalam hubungannya dengan perjalanan Islam di Lombok khususnya dan Nusantara pada umumnya. Karena kawasan ini secara geografis terletak pada pinggiran dunia Muslim. Terdapat kecenderungan para peneliti di masa modern ini untuk tidak memasukkan Nusantara dalam pembaruan tentang Islam. Diasumsikan, Islam di kawasan ini tidak mempunyai tradisi keilmuan yang mantap. Bahkan Islam di Nusantara dianggap bukan Islam yang sebenarnya, karena dianggap masih bercampur dengan budaya lokal. ${ }^{50}$ Mereka menyimpulkan Islam di Nusantara berbeda dengan Islam di Timur Tengah. Tentu saja pendapat seperti itu tidak bisa kita menolaknya, tetapi untuk mengatakan bahwa tradisi Islam di Nusantara tidak mempunyai kaitan dengan Islam di Timur Tengah adalah pendapat yang keliru.

Hubungan antara kaum Muslimin di kawasan Melayu Indonesia dan Timur Tengah telah terjalin melalui proses ibadah haji. Terdapat sejumlah penuntut ilmu dari Nusantara termasuk dari Lombok yang terlibat dalam jaringan ulama, terutama setelah menuntut ilmu di Timur Tengah (khususnya Makkah dan Madinah). Sebagian besar dari mereka kembali ke tempat asalnya menjadi tansmitter utama tradisi intelektual keagamaan dari pusat keilmuan di Timur Tengah ke pulau Lombok. Kelompok inilah selanjutnya yang dikenal dengan sebutan "Tuan Guru", yang perilakunya digugu dan ditiru.

\section{Catatan Akhir}

Terdapat bukti-bukti historis yang kuat bahwa agama Islam masuk di pulau Lombok sekitar abad ke- $16 \mathrm{M}$, melalui jalur dari Barat. Penyebarnya yang terkenal adalah satu ekspedisi dari Jawa di bawah pimpinan Sunan Prapen putera Sunan Giri (salah satu Wali Songo). Boda adalah agama asli etnis Sasak sebelum agama Islam menjadi anutan mereka. Penganut Boda ini bahkan mengklaim diri mereka sebagai pengikut "Agama Majapahit".

Agama Islam berkembang melalui pendekatan sistem berantai tiga. Kiai yang datang dari Jawa diharuskan mendidik tiga orang. Apabila tiga orang yang dididik itu sudah dianggap memiliki otoritas keagamaan memadai, selanjutnya dilantik menjadi kiai. Pendekatan ini menimbulkan kesan seolaholah kiai saja yang memiliki kewajiban melaksanakan ajaran-ajaran agama

${ }^{50}$ Cliffort Geertz, Abangan, Santri, Priyai dalam Masyarakat Jawa (Jakarta: Pustaka Jaya, 1983), 123. 
seperti shalat dan puasa. Dalam tataran empirik hal ini melahirkan dua kelompok sosial yaitu kelompok kiai dan kelompok pengikut kiai yang masih sangat awam.

Islam yang diperkenalkan oleh Sunan Prapen dan penerusnya, hanya menekankan konsep keimanan dan ketauhidan dengan pendekatan budaya. Pembinaan Islam yang diutamakan adalah kesadaran ketuhanan, dan ibadah yang bernuansa sufistik. Pola sufisme sinkretik dipandang efektif untuk syiar Islam saat itu dan lebih mudah diterima. Melalui metode ini kiranya Islam sudah tersebar di seluruh Lombok hingga penghujung abad ke-17 M.

Upaya islamisasi untuk mendakwahkan ajaran Islam yang lebih sempurna-pasca Sunan Prapen_dilanjutkan oleh para Tuan Guru melalui majelis-majelis taklim dan pondok pesantren dan mengadakan jaringan (baca: network) dalam bidang pendidikan dan dakwah dengan para ulama di Timur Tengah, sehingga hubungan emosional umat Islam Lombok dengan ulama Timur Tengah, cukup kental. Hal ini setidak-tidaknya dapat dibuktikan dengan penghargaan yang sangat tinggi terhadap anggota masyarakat yang pulang atau pergi ke Makkah walaupun hanya sebagai tenaga kerja. 